\title{
Empirical analyses of excavation method and tunnel support system based on engineering geology of Tunnel No.8 at Jakarta - Bandung high-speed railway, West Bandung, Province of West Java, Indonesia
}

\author{
Ika Medika Ayu Oktarina ${ }^{1}$, Subagyo Pramumijoyo ${ }^{1}$, and I Gde Budi Indrawan ${ }^{\text {* }}$ \\ ${ }^{1}$ Geological Engineering, Faculty of Engineering, Gadjah Mada University, 55281 Yogyakarta, Indonesia
}

\begin{abstract}
The Chinese Basic Quality (BQ) system was used to determine the rock mass classes and design tunnel support system of the Tunnel No.8 of the Jakarta-Bandung high-speed railway. As the BQ system is newly applied for tunnelling project in Indonesia and remains poorly understood, this research aims to determine rock mass classes at the tunnel construction site and propose the tunnel excavation method and support system alternative based on more widely used rock mass classifications of the Geological Strength Index (GSI) and Japan Society of Civil Engineers (JSCE) standard. Surface engineering geological mapping and evaluation of drill core samples were carried out to obtain accurate interpretation of subsurface engineering geological conditions, particularly the rock mass classes at the tunnel elevation. The results show that the tunnel construction area consists of very poor to fair classes of andesite breccia, tuff lapilli, and tuffaceous sandstone. The full-face method with auxiliary bench cut and multiple-bench cut method are to be applied at the tunnel sections consisting of rock mass classes CI and DII, respectively. The proposed tunnel support system is a combination of shotcrete, rock bolt, steel rib, and invert.
\end{abstract}

\section{Introduction}

The Jakarta - Bandung High-Speed Project, which was built to increase the potential for developing industry, trade, and tourism, has a $142.3 \mathrm{~km}$ line with plans to construct 13 tunnels, one of which is Tunnel No. 8 . Tunnel No. 8 is located on DK $97+320$ to DK $99+510$ with a length of $2190 \mathrm{~m}$. The research location lay on Mandalasari Village, Cikalong Wetan District and Sumur Bandung Village, Cipatat District, West Bandung Regency, West Java Province. The research location can be seen in Figure 1.

The tunnel built to accommodate a double railway track is located on a hill with undulating topography and hills covered with vegetation. The inlet is located in a flat area, while the outlet is located in a hill area with dense traffic. A Tunnel is one of underground construction that requires many factors. Factors that need to be considered are the planning stage to the maintenance, and social impact after the tunnel is operational. That kind of factor makes the construction of a tunnel such complex construction. One of the crucial factors in planning and construction steps is the characterization of engineering geology conditions in a tunnel construction area and its surrounding.

The study area is dominated by Quaternary Formation of Older Volcanic Product (Qob) and some Miocene Cantayan Formation based on The Regional Geological Map of Cianjur Sheet[1]. The rock mass classification used in this project uses the BQ classification system adopted from the only national system suitable for most types of rock engineering in China. This study will identify rock mass classification using GSI.

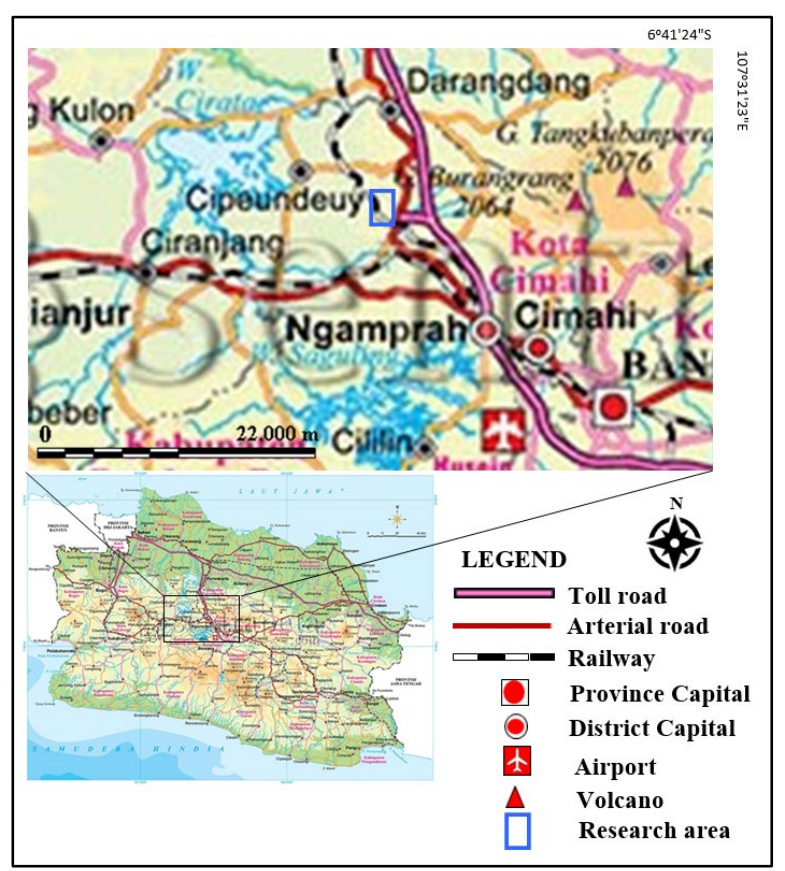

Fig. 1. Map of research location (Tunnel No 8).

\footnotetext{
*Corresponding author: igbindrawan@ugm.ac.id
} 
Uniaxial Compressive Strength (UCS) values in the field and weathering conditions of surface rocks are estimated based on observations in the field and determined using empirical methods. These data are instrumental in determining the excavation method and support system at an early stage empirically.

\section{Regional geology}

According to van Bemmelen[2], the physiographic conditions of West Java are divided into 4 (four) zones: Jakarta Coastal Plains Zone, Bogor Zone, Bandung Zone, and the Southern Mountain Zone. Physio graphically, the research area is located in the Bandung Zone, where most of the zone forms younger volcanic deposits from the surrounding volcanoes.

The Regional Geological Map of Cianjur Sheet with a scale of 1:100,000 compile by Sudjatmiko[1] shows the regional stratigraphy of the Jatiluhur Formation (Mdm), Cantayan Formation (Mtts), and Older Volcanic Products (Qob). Marl and quartz sandstone member of Jatiluhur Formation the aged of Miocene consist of dark grey marl, marly claystone, and clayey shale with intercalations of quartz sandstone, quartzite, and marly limestone. Sandstone members of the Cantayan Formation's aged Miocene consist of well-bedded dirty sandstone, sandy shale, shaly clay, marine breccia, and conglomerate. Older volcanic products in the age of Pleistocene consist of breccia lahar lava, volcanic breccia, flow breccia, lahar deposits, and lava showing sheet and columnar jointing. The composition is between andesite and basalt. The Regional Geological Map shows that the research area is located in the Cantayan Formation (Mtts) and the Older Volcanic Products (Qob). Formation is shown in Figure 2.

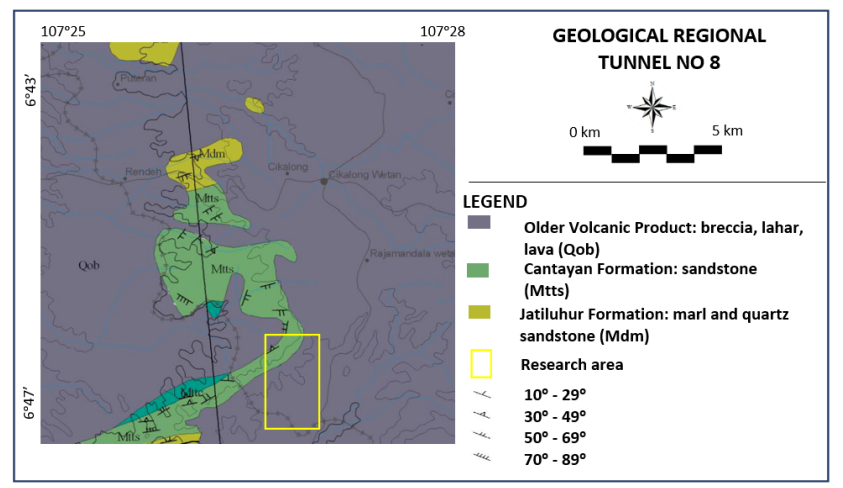

Fig. 2. The geological map of the research area is part of the Regional Geological Map of Cianjur sheet[1].

\section{Methodology}

Engineering geology conditions of the research area are compiled based on primary data collected during surface mappings, such as surface geological conditions and surface GSI value measurements. Surface engineering geological mapping was carried out to result from inaccurate interpretation of subsurface engineering geological conditions, including the rock mass classes at the tunnel elevation. The data were used as material in making Geological Maps, and surface rock mass class maps with a scale of 1:10,000. The subsurface database on core drill analysis for rock mass classes subsurface. The naming of pyroclastic rocks is based on the grain size of the constituent material based on Fisher Classification[3].

Determination of the degree of rock weathering in the field using a degree of rock weathering classification of rock mass according to International Society for Rock Mechanics (ISRM)[4]. The estimated value of Uniaxial Compressive Strength (UCS) in the field using an estimation table for UCS values in the field for intact rock according to Hoek[5].

Measurement of rock mass classes on the surface using basic chart of Geological Strength Index (GSI) system developed by Marinos and Hoek[6], while the subsurface measurement using quantitative chart of the Geological Strength Index (GSI) system which is regarding the factor of discontinuity conditions and value of 0.5 Rock Quality Designation (RQD) developed by Bieniawski and Hoek et al.[7,8].

The result of the determination of GSI value is correlated with the table correlation of the GSI classes value of rock mass by Sivakugan et al.[9](Table 1).

Table 1. Correlation of the GSI classes value of rock mass[9]

\begin{tabular}{|c|c|}
\hline GSI value & Rock Mass Classes \\
\hline$<20$ & Very poor \\
\hline $21-40$ & Poor \\
\hline $41-55$ & Fair \\
\hline $56-75$ & Good \\
\hline $76-95$ & Very Good \\
\hline
\end{tabular}

Excavation methods and tunnel support systems are determined based on the rock/soil category listed in the Japan Society of Civil Engineers (JSCE)[10]. Apart from the rock/soil category, the tunnel excavation method is chosen by considering the advantages and disadvantages of each method and the appropriate media condition.

When excavating the tunnel, selecting the support and support system typically uses an empirical approach consisting of shotcrete, rock bolts, steel rib, and invert. The selection is also determined by the rock/soil category.

\section{Result and discussion}

\subsection{Lithological condition}

The lithology of the study area was determined based on observations of outcrops found around the tunnel site. Outcrops found along the tunnel body and its surroundings are dominated by settlements and plantations. The study area is dominated by volcanic rocks from the Qob Formation in the form of andesite breccia and tuff lapilli seen from the grain size of the constituent materials. Meanwhile, an outcrop of 
tuffaceous sandstone was found in an older formation, namely the Mtts formation (Figure 6).

\subsubsection{Tuffaceous sandstone}

Tuffaceous sandstone outcrops appear in Cantayan Formation member of sandstone (Mtts) based on the Regional Geological Map of Cianjur sheet. The distribution of this unit covers $6.5 \%$ of the research area with brownish-grey to blackish brown colour (Figure 3). This unit has a massive structure layered with fragments measuring 1-2 mm and a matrix of $<0.01 \mathrm{~mm}$ in size. Based on observations in the field, this tuffaceous sandstone is in slightly weathered condition with discoloration of the rock and surface discontinuities.

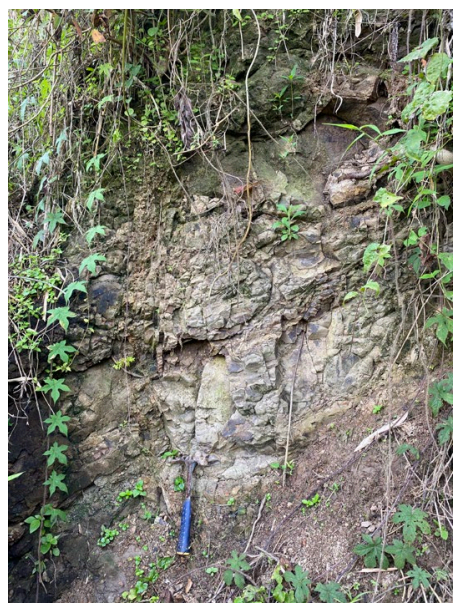

Fig. 3. Slightly weathered tuffaceous sandstone.

\subsubsection{Andesite Breccia}

This unit is part of Older Volcanic Products (Qob). The geological map shows that andesite breccia units are spread almost $85 \%$ of the research area. Based on surface observation, andesite breccia units predominantly dark red-brow in the residual soil area and dark brown to dark yellow in highly to moderately weathered. Fragments $5-50 \mathrm{~mm}$ in size, even $>64 \mathrm{~mm}$, were dominated by andesite fragment and matrix of $<2$ $\mathrm{mm}$ in size.

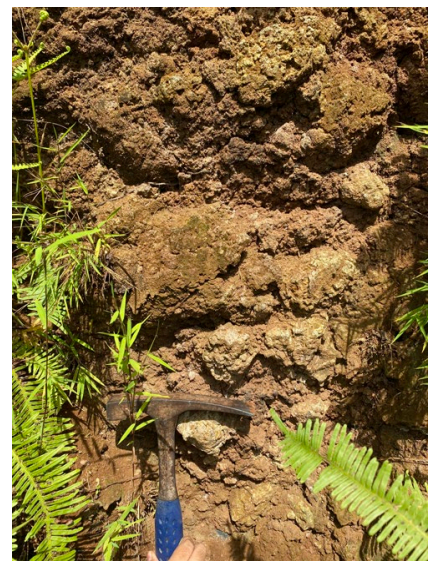

Fig. 4. Moderately weathered andesite breccia.

\subsubsection{Tuff Lapilli}

Outcrops of tuff lapilli units showed on the top of the andesite breccia unit, which is also part of Older Volcanic Products (Qob). The distribution of tuff lapilli unit is around $8.5 \%$ of the total research area on the southwestern side. The size of the fragment is relatively uniform, which is about $<2 \mathrm{~mm}$ and matrix $<1 \mathrm{~mm}$. The naming of this unit is based on Fisher's classification[3].

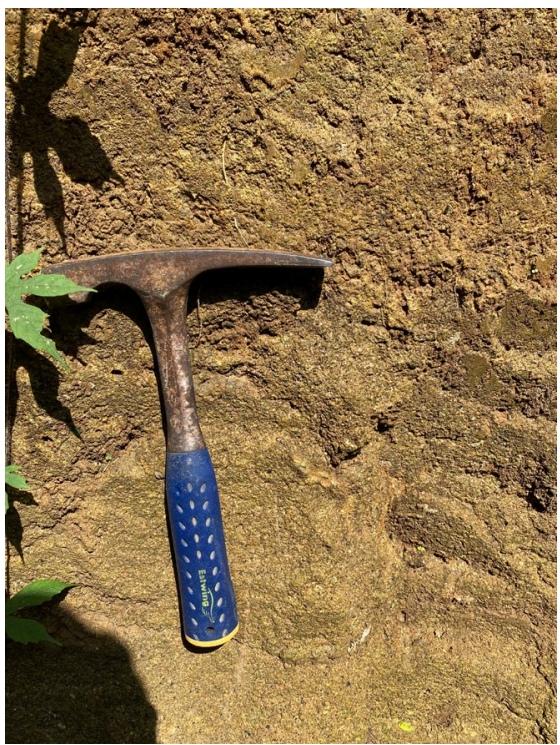

Fig. 5. Moderately weathered tuff lapilli.

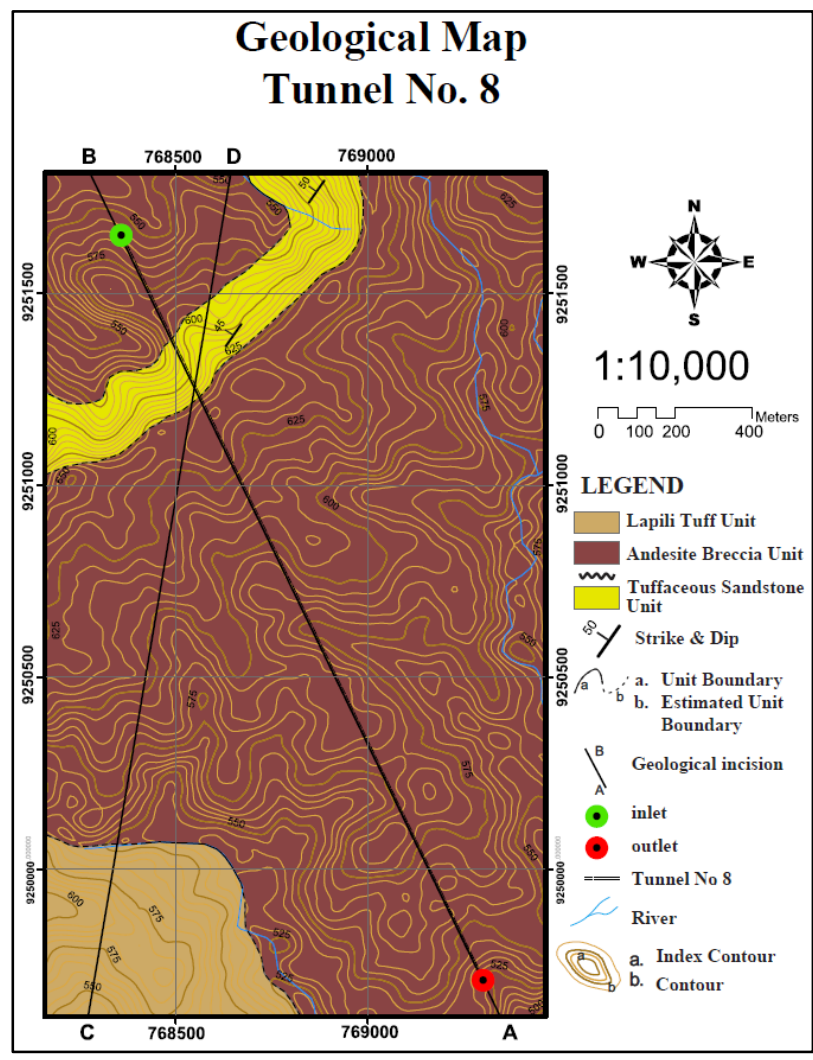

Fig. 6. Geology Map Tunnel No. 8. 


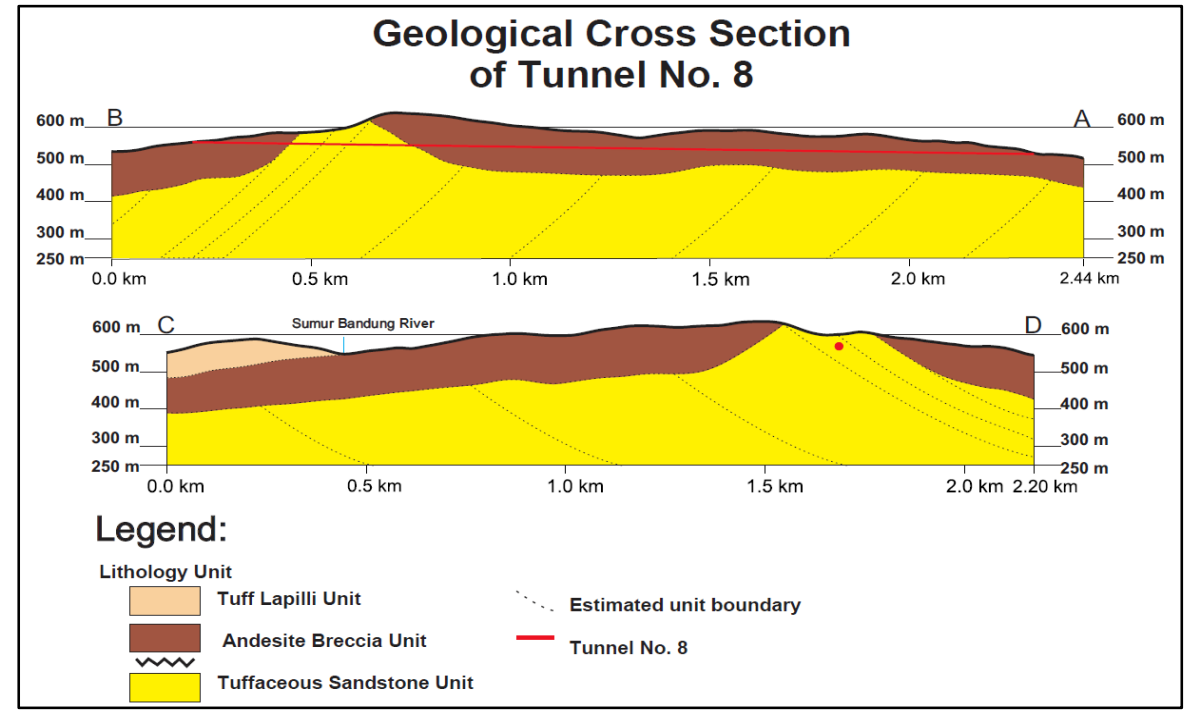

Fig. 7. Geology Crossed Section Tunnel No. 8.

\subsection{Engineering classification of rock mass}

The surface engineering geological map is prepared based on the degree of weathering and the quality of the GSI rock mass obtained from outcrop observations in the field. Qualitative assessment of rock weathering degree on surface outcrops at the Tunnel No. 8 construction based on ISRM[4] and an estimated value of UCS based on Hoek[5]. From these data, the geological engineering units found in this study area[4] can be divided into 5 (five) rock units: residual soil, moderately weathered tuff lapilli, highly weathered andesite breccia, moderately weathered andesite breccia, and slightly weathered tuffaceous sandstone (Figure 8).

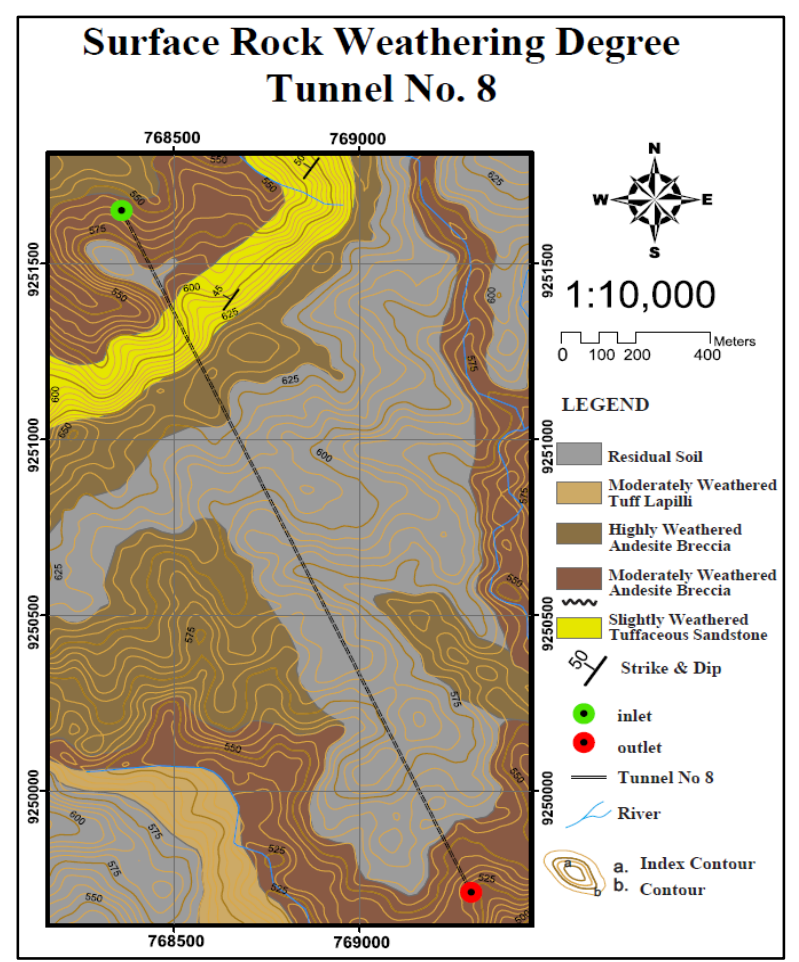

Fig. 8. Map of surface rock weathering degree in research area.
The value of Geological Strength Index (GSI) surface rock was obtained from field investigation on outcrop by referring to GSI basic chart according to Marinos and Hoek[6] (Figure 9). The GSI value on the basic chart is determined based on surface conditions and the discontinuous structure; then, these values are correlated with rock mass classes using the Sivakugan correlation table (Table 1). Based on surface observation, the value of GSI surface rock can be divided from very poor (GSI value of $0-20)$ to fair (GSI value of 41-55) (Figure 10).

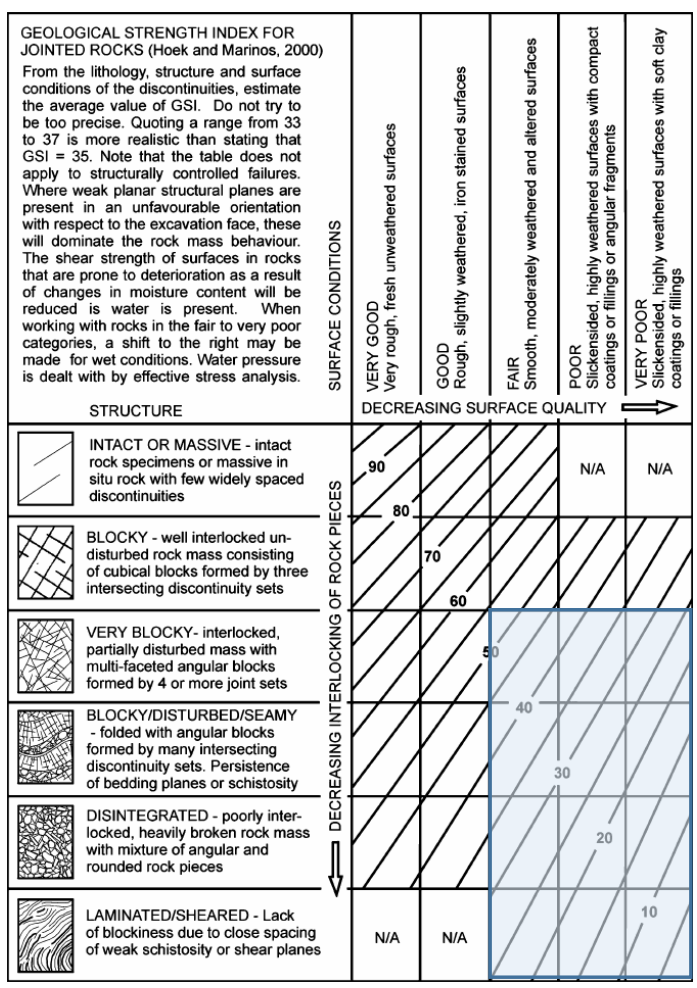

Fig. 9. GSI value of study area. 


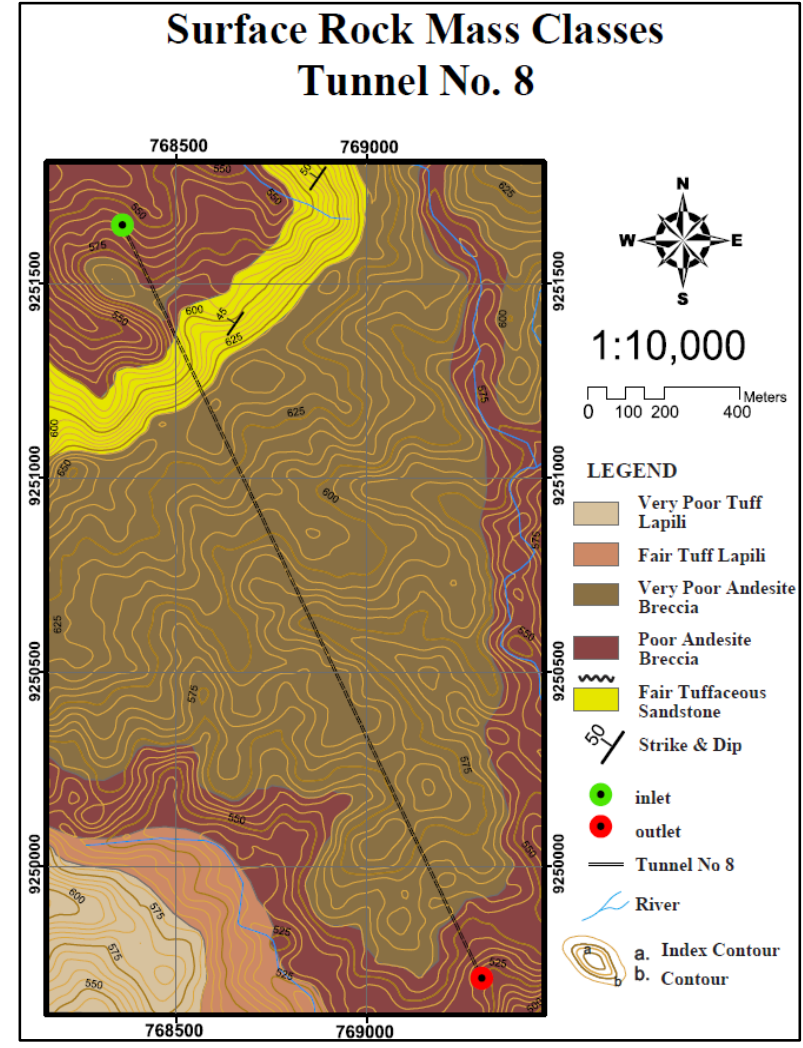

Fig. 10. Map of surface rock mass classes.

\subsubsection{Residual soil unit}

Most of the outcrops defined as residual soil are tea and cassava plantations. In this case, the Reddish-dark brown color due to the weathering process of older rocks is from andesite breccia. The thickness of this unit is around $5-15 \mathrm{~m}$ from the surface. Based on Hoek[5], residual soil can be state has $\mathrm{UCS}$ value $<1 \mathrm{MPa}$.

\subsubsection{Highly weathered andesite breccia unit}

The colour of this unit is dark brown. The rock texture is poorly sortation, matrix-supported, with a fragment grain size of $0.01 \mathrm{~m}-2 \mathrm{~m}$, a matrix grain size of $<2 \mathrm{~mm}$ with structural rocks of massive. Rock fragments composed of andesite and matrix are composed of sandy material. The value of intact rock strength is between 1$5 \mathrm{MPa}$, which is classified as R1 (very weak) with GSI value $10-20$.

\subsubsection{Moderately weathered andesite breccia unit}

The color of this unit is brown to yellowish-brown with rock texture is poorly sortation, matrix-supported, the fragment grain size of $0.01 \mathrm{~m}-2 \mathrm{~m}$, the matrix grain size of $<2 \mathrm{~mm}$ and with structural rocks of massive. Rock fragments composed of andesite and matrix are composed of sandy material. The value of intact rock strength is between 5-25 MPa with a GSI value 30-40.

\subsubsection{Moderately weathered tuff lapilli unit}

The color of this unit is light brown to yellowish-brown with rock texture is well sortation, fragment supported, composed by the pyroclastic material size of $>2 \mathrm{~mm}$ intact rock strength of moderately weathered tuff lapilli unit is 5-25 MPa with GSI value 45-50 (fair) and 15-20 (very poor).

\subsubsection{Slightly weathered tuffaceous sandstone unit}

The colour of this unit is yellowish-brown with rock texture is well sortation, fragment supported, composed by the pyroclastic material size of $<2 \mathrm{~mm}$, grain size $0.05-0.1 \mathrm{~mm}$ from very fine sand to fine sand, intact rock strength of slightly weathered tuffaceous sandstone unit is 5-25 MPa with GSI value 40-50 (fair).

\subsubsection{Subsurface condition}

Subsurface conditions were estimated by the description of the core drill around the tunnel. Measurements were made on joint conditions and RQD measurements. GSI value of subsurface estimated by measurement using a quantitative chart of the GSI system based on Hoek et al. (2013) and Bieniawski (1989)[7,8], which is regarding the factor of joint conditions per 1 meter and value of 0.5 RQD. Observations of weathering conditions of core drills were also carried out, considering the surface conditions had a relatively high degree of weathering. Classification of subsurface rocks on core drill samples can be divided into 5 (five) units: highly weathered andesite breccia, moderately weathered andesite breccia, slightly weathered tuffaceous sandstone, and highly weathered claystone units.

The residual soil is predominantly reddish-dark brown, visible plant roots, in crushed condition (dry condition) or looks clayey (wet condition), RQD and GSI values are 0 (zero). Andesite breccia units were seen in the majority of core samples, from very poor to good quality. Moderately weathered andesite breccia can be found in core number 8 at depths of more than 50 meters from the surface with a predominantly blackish brown color, the RQD value is around 75-100 and combined with the joint condition values so that the GSI value is between 56 to 64 (good). Moderately weathered andesite breccia is also found in core numbers 7 and 8 at the depths of between 27 to over 50 meters, and combining the joint condition values with RQD, GSI values are obtained between 41-55 (fair). Highly weathered andesite breccia with greyish brown and brownish yellow color can be found in several core samples at a depth between 16-50 meters. The core conditions are mainly in a broken state with an RQD value of 10-65. This value is combined with the value of the joint condition, and then the GSI value is obtained between 21-40 (poor). Very poor breccia units were found in almost all core samples, with more than half of the rock is crushed or turned into the soil (highly 
weathered degree). They were located after the residual soil layer with a GSI value of less than 20.

Tuffaceous sandstone units are seen in core samples taken at The Mtts Formation site, particularly core number 3 with slight weathering conditions. Based on the value of RQD and joint conditions, the GSI values varied from very poor (0-20) to very good (76-95). Highly weathered claystone units were found in several core samples with GSI values ranging from very poor (0-20) to poor (21-40) (Figure 11).

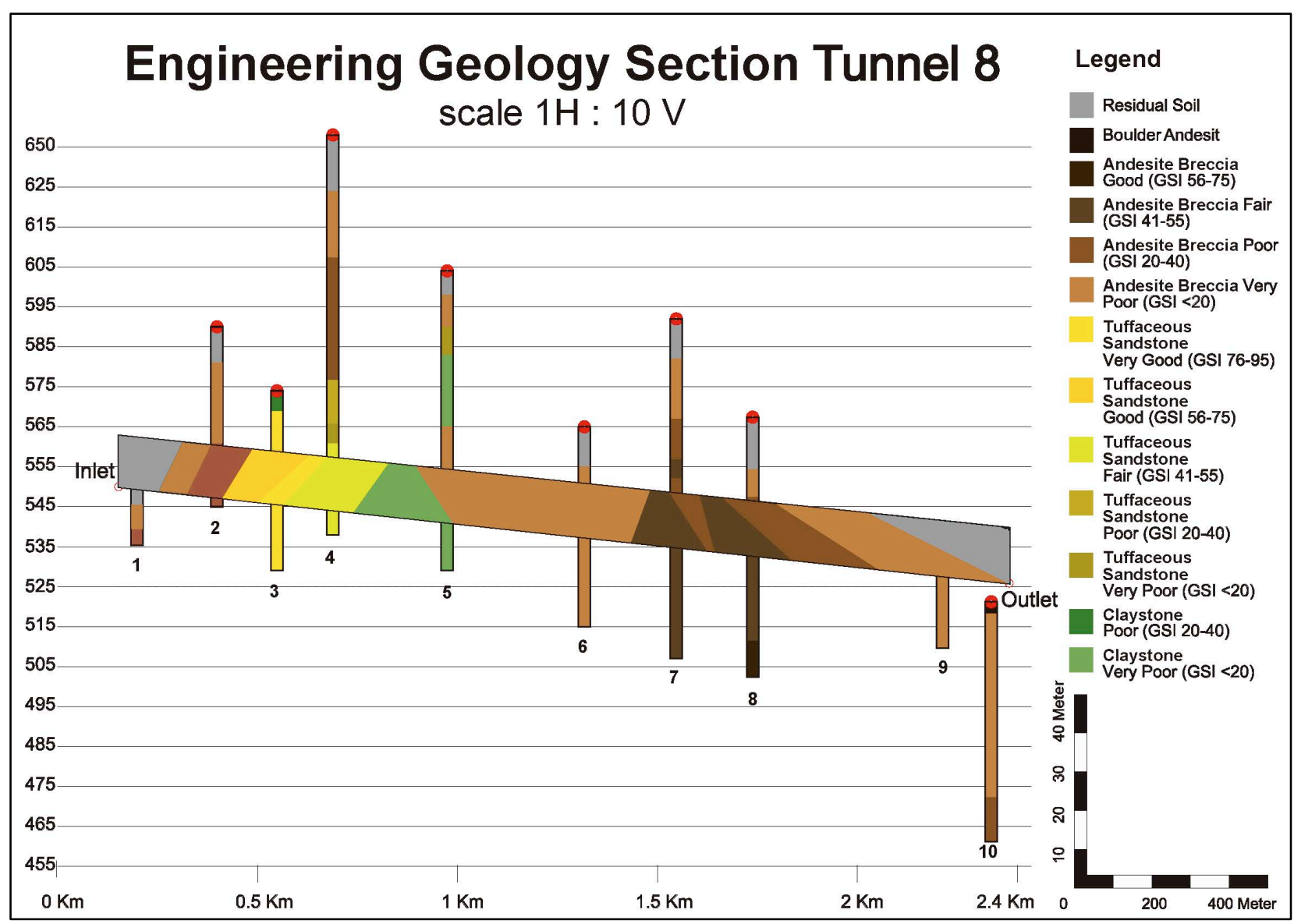

Fig. 11. Map of subsurface rock mass classes based on GSI value.

\subsection{Excavation methods and tunnel support system}

Rock/soil category is determined based on JSCE (2018)[10] by considering geological conditions and the condition of core drill in the tunnel elevation. It can be seen that both the tunnel elevation and the surface condition of the study area are dominated by andesite breccia and sandstone. The tunnel section of the Mtts Formation area has an RQD value of 40-100; the rock condition is relatively hard, although signs of weathering are visible, and there are no visible discontinuities caused by water. Based on the geological conditions and core drill conditions, the rock/soil category can be determined as class CI (represent tuffaceous sandstone). The tunnel section of the Qob Formation area has an RQD value of 10 or less, and the drill core is in the form of small pieces, but sometimes it is clay or sand mixed with rock fragments. Some of the rocks are fresh, but most of them are weathered or altered quite strongly. The rock/soil category can be defined as class DII (represent andesite breccia) based on these data.

The excavation method that can be used in rock class $\mathrm{CI}$ is the full-face method with auxiliary bench cut.
Meanwhile, in class DII, the excavation method can be used multi-bench cut method. This excavation method considers the good media condition but interspersed with the bad media in the rock category CI class and considering poor media and requiring a small section of heading to stabilize the dig face in the rock category DII.

Based on JSCE (2018)[10], it can be decided that the suitable support type for rock class CI is shotcrete and rock bolt. The use of invert is also very effective, considering the condition of rocks that have many fractures. Whereas in rock class DII, in addition to using the support type as in-class CII, steel rib is also required to be installed immediately on the excavation face.

Scheme of support system based on JSCE (2018)[10], the length of the excavation rate is $1.5 \mathrm{~m}$ in rock category $\mathrm{CI}$. The length of rock bolts is $4,0 \mathrm{~m}$, with a distance at arc 1,2 $\mathrm{m}$ and longitudinal 1,5 m mounted on top heading and bench. Shotcrete thickness is $15 \mathrm{~cm}$. The thickness of the lining is $40 \mathrm{~cm}$ on the arc and sidewall. The length of the excavation rate is $1,0 \mathrm{~m}$ or less in rock category DII. The length of rock bolts is 6,0 $\mathrm{m}$, with a distance at arc $1,0 \mathrm{~m}$ and longitudinal $1,0 \mathrm{~m}$ or less mounted on top heading and bench. Shotcrete thickness is $25 \mathrm{~cm}$. The lining thickness is $40 \mathrm{~cm}$ on the arc and the sidewall with $50 \mathrm{~cm}$ on the invert. Steel rib 
using H-200, both for top heading and bench, with a 1,0 $\mathrm{m}$ or less distance. The deformation permit on category DII is $10 \mathrm{~cm}$.

\section{Conclusion and recommendation}

The lithology of the research area consists of 3 (three) units, namely tuff lapilli, andesite breccia, and tuffaceous sandstone. Weathering conditions of surface rocks vary from slightly weathered to residual soil. Based on the surface mapping, the rock mass classes are divided into very poor tuff lapilli, fair tuff lapilli, very poor andesite breccia, poor andesite breccia, and fair tuffaceous sandstone with GSI value from 0-20 (very poor) to 41-55 (fair). In comparison, subsurface rock mass classes vary from very poor (GSI value: 0 -20) to very good (GSI value: 76-95). The body of the tunnel is dominated by andesite breccia and tuffaceous sandstone.

The excavation method used is the full-face method with an auxiliary bench cut (CI) and a multiple-bench cut method (DII). The support system used is shotcrete, rock bolts, and linings for rock category CI. While rock category DII added steel rib and invert. Deformation is only permitted in rock category DII. The inlet and outlet of the tunnel are the parts that need attention. Rock mass classes of inlet and outlet tunnels are very poor, so it is necessary further to analyses the slope stability of inlet and outlet tunnels.

Further study, particularly by numerical method, is required to compare the performance of the tunnel support system proposed in this study to the support system applied in the field, which is based on the China National Standard.

The authors would like to thank the owner of Jakarta Bandung High-Speed Railway Project PT. Kereta Cepat Indonesia - China (PT. KCIC), High-Speed Railway Contractor Consortium (HSRCC), China Railway Engineering Corporation (CREC) and China Railway Design Corporation (CRDC) for research permit and data access permission. Financial support from The Ministry of Public Works and Housing of Indonesia is gratefully acknowledged.

\section{References}

1. Sudjatmiko, Geological Map of The Cianjur Quadrangle, Jawa (2003)

2. R.W. van Bemmelen, The Geology of Indonesia Volume IA General Geology of Indonesia and Adjacent Archipelagoes (The Hague, 1949)

3. R.V. Fisher, Earth-Sci. Rev. 1, 287-298 (1966)

4. ISRM, Int. J. Rock Mech. Min. Sci. \& Geomech. Abstr. 15, 319-368 (1978)

5. E. Hoek, Practical Rock Engineering (RocScience, 2007)

6. P. Marinos, E. Hoek, GSI: A geologically friendly tool for rock mass strength estimation, in ISRM Int Symp (2000)
7. Z.T. Bieniawski, Engineering rock mass classifications: a complete manual for engineers and geologists in mining, civil, and petroleum engineering (John Wiley\&Sons, New York, 1989)

8. E. Hoek, T.G. Carter, M.S. Diederichs. Quantification of the Geological Strength Index Chart, in US Rock Mech/Geomech Symp, 47 (2013)

9. N. Sivakugan, S.K. Shukla, B.M. Das, Rock Mechanics: an introduction (CRC Press, Florida, 2013)

10. JSCE. Standard Specifications for Tunneling2016: Mountain Tunnels. Japan (2018) 